\title{
A plazmában keringó szabad DNS jellemzői és diagnosztikai alkalmazási lehetőségei vastagbélrák esetén
}

\author{
Barták Barbara Kinga dr. ${ }^{1}$. Márkus Eszter dr. ${ }^{1}$ \\ Kalmár Alexandra dr., ${ }^{1,2}$ - Galamb Orsolya dr. ${ }^{1,2}$ \\ Szigeti Krisztina Andrea ${ }^{1}$ - Nagy Zsófia Brigitta ${ }^{1}$ - Zsigrai Sára dr. ${ }^{1}$ \\ Tulassay Zsolt dr..$^{1,2}$. Dank Magdolna dr. ${ }^{3}$ \\ Igaz Péter dr. ${ }^{1,2}$ - Molnár Béla dr. ${ }^{1,2}$ \\ ${ }^{1}$ Semmelweis Egyetem, Általános Orvostudományi Kar, II. Belgyógyászati Klinika, Molekuláris \\ Gasztroenterológia Laboratórium, Budapest \\ ${ }^{2}$ Magyar Tudományos Akadémia, Molekuláris Medicina Kutatócsoport, Budapest \\ ${ }^{3}$ Semmelweis Egyetem, Általános Orvostudományi Kar, Onkológiai Központ, Budapest
}

\begin{abstract}
A vastagbélrák (CRC) incidenciája és mortalitása is kiemelkedően magas a közép-európai országokban, hazánkban a második leggyakoribb daganattípus mind a férfiak, mind a nők körében. Az évente újonnan regisztrált betegek száma 10000 köré tehető. Ezek az adatok jelzik, hogy szükséges olyan szúrőmódszerek kifejlesztése, amelyek a betegek számára kevéssé megterhelőek, ezáltal növelhető a vizsgálatokon történő részvétel. A vérben található, sejten kívüli szabad DNS (skDNS) szintje bizonyos fiziológiás állapotokban megnő, többek között terhesség vagy erőteljes fizikai aktivitás esetén. Az skDNS koncentrációja azonban egyes kórállapotokban, például autoimmun és gyulladásos megbetegedésekben, valamint különböző daganattípusokban, többek között vastagbélrákban is emelkedett értéket mutat. Az skDNS eredetére, funkciójára és hatásmechanizmusára vonatkozóan számos tanulmány található a szakirodalomban. Jelen összefoglaló közleményünk célja a szabad DNS mennyiségi és minőségi változásainak ismertetése, funkcióinak áttekintése, valamint diagnosztikus alkalmazási lehetőségeinek bemutatása a vastagbélrák korai észlelésének szempontjából. A szabad-DNS-molekulák többféle módon kerülhetnek a keringésbe, az apoptózis és nekrózis mellett az élő sejtek által történő direkt szekréció is lehetséges. Daganat kialakulása esetén az egészséges és a rákos sejtek egyaránt képesek DNS-t kibocsátani a perifériás vérbe, így a tumorsejtekben bekövetkező genetikai (például mutáció: $A P C, K R A S, B R A F$ ) és epigenetikai (például DNS-metiláció: SEPT9, SFRPI) elváltozásokat a szabadDNS-frakcióban is vizsgálhatjuk. Számos nagy áteresztőképességü, érzékeny és automatizált módszer is rendelkezésünkre áll, amelyek lehetőséget biztosítanak a minták standardizált feldolgozására, illetve a markerek kvantitatív elemzésére. Ezek a fejlesztések segíthetnek különböző alternatív szűrési módszerek kialakításában, amelyek a klinikai gyakorlatba is könnyedén beépíthetők, így hozzájárulhatnak a betegségek mielőbbi diagnosztizálásához.
\end{abstract}

Orv Hetil. 2019; 160(30): 1167-1177.

Kulcsszavak: sejten kívüli DNS, plazma, vastagbélrák, DNS-metiláció, mutáció

\section{Characteristics and diagnostic applications of circulating cell-free DNA in colorectal cancer}

The incidence and mortality of colorectal cancer (CRC) are considerably high in Central European countries, it is the second most common cancer in both men and women in Hungary with 10,000 newly registered patients per year. These data indicate the necessity of new screening methods that are more comfortable for patients, hence the compliance can be increased. Cell-free DNA (cfDNA) level in blood is elevated in certain physiological conditions, such as pregnancy or high physical activity. Furthermore, cfDNA concentration alterations can also be detected in some pathological processes; increased cfDNA amount was observed in autoimmune and inflammatory diseases, as well as in various cancers including CRC. Numerous studies about origin, function, and mechanism of cfDNA can be found in the scientific literature. In this review, we aimed to describe the quantitative and qualitative changes of cfDNA, to

A Szerkesztôség felkérésére készített tanulmány. 
present its functions, and to provide an overview of the available diagnostic applications for CRC. CfDNA can be released to the circulatory system via apoptosis, necrosis or by direct secretions by living cells. In cancer patients, cfDNA can originate from healthy and cancer cells, hence genetic (e.g. mutations in APC, KRAS, BRAF) and epigenetic (e.g. methylation in SEPT9, SFRPI) alterations of tumor cells can be examined in cfDNA fraction. Several highthroughput, sensitive and even automated methods are available providing opportunity to perform standardized sample preparation and to analyse biomarker candidates quantitatively. These enhancements can help to develop alternative screening methods that can be easily integrated into the clinical practice and can contribute to early cancer detection.

Keywords: cell-free DNA, plasma, colorectal cancer, DNA methylation, mutation

Barták BK, Márkus E, Kalmár A, Galamb O, Szigeti KA, Nagy ZsB, Zsigrai S, Tulassay Zs, Dank M, Igaz P, Molnár B. [Characteristics and diagnostic applications of circulating cell-free DNA in colorectal cancer]. Orv Hetil. 2019; 160(30): 1167-1177.

(Beérkezett: 2019. március 19.; elfogadva: 2019. április 17.)

\section{Rövidítések}

$\mathrm{AD}=$ adenoma; $A L X 4=$ Aristaless-like homeobox- 4 gén; $A P C$ $=$ adenomatosus polyposis coli gén; $\mathrm{BCATl}=($ branched chain amino acid transaminase 1 ) elágazó láncú aminosav-transzamináz- $1 ; \mathrm{BE}=$ bystandereffektus; $B R A F=$ (rapidly accelerated fibrosarcoma B) B-Raf protoonkogén; $\mathrm{CpG}=$ (cytosine-phosphate-guanine) citozin-foszfát-guanin dinukleotid; $\mathrm{CRC}=$ (colorectal cancer) vastagbélrák; DAPKl $=($ death associated protein kinase 1) halálasszociált proteinkináz-1; DNáz = dezoxiribonukleáz; DHPLC $=($ denaturing high-performance liquid chromatography) denaturáló nagy hatékonyságú folyadékkromatográfia; DNS = dezoxiribonukleinsav; E-cad = E-kadherin; ELISA $=$ (enzyme-linked immunosorbent assay) enzimhez kapcsolt immunszorbensteszt; FDA $=($ Food and Drug Administration) az Egyesült Államok Élelmiszer és Gyógyszer-engedélyeztetési Hivatala; FHIT $=($ fragile histidine triad protein $)$ fragilis hisztidintriád-fehérje; FIT = (fecal immunochemical test) immunalapú székletvér-vizsgálat; HELPP-szindróma = (hemolysis, elevated liver enzymes, low platelet count) hemolízissel, emelkedett májenzimértékekkel és alacsony vérlemezkeszámmal járó szindróma; HUVEC = (human umbilical vein endothelial cells) humán köldökvéna-endothelsejtek; $I K Z F I=$ (IKAROS family zinc finger l) IKAROS-család cinkujj-1 gén; $K R A S=($ Kirsten rat sarcoma oncogene $)$ Kirsten-patkány-sarcoma virális onkogén; MeDIP = (methylated DNA immunoprecipitation) metilált-DNS-immunprecipitáció; MetCap = methyl capture szekvenálás; $\mathrm{MPO}=$ mieloperoxidáz enzim; NET $=$ (neutrophil extracellular trap) neutrophil extracelluláris csapda; NGS = (next generation sequencing) új generációs szekvenálás; NPY = neuropeptid $\mathrm{Y} ; \mathrm{NRAS}=$ neuroblastoma RAS onkogén; PCR = (polymerase chain reaction) polimerázláncreakció; $\mathrm{PENK}=$ proenkefalin; $\mathrm{PNA}-\mathrm{PCR}=$ (peptide nucleic acid-polymerase chain reaction) peptid-nukleinsav polimeráz-láncreakció; PRIMAI = (proline rich membrane anchor 1$)$ prolingazdag membránhorgony-1; RNáz = ribonukleáz; RT-PCR $=$ (real-time polymerase chain reaction) valós idejü polimeráz-láncreakció; SDC2 = szindekán-2; SEPT9 = septin-9; SFRPl $=($ secreted frizzled related protein 1$)$ szekretált frizzled-rokon fehérje-1; SFRP2 $=$ (secreted frizzled related protein 2) szekretált frizzled-rokon fehérje-2; skDNS = sejten kívüli DNS; SLE = (systemic lupus erythematosus) szisztémás lupus erythematosus; SMAD4 = a SMAD-család 4. tagja; SSCP $=($ single strand conformation polymorphism $)$ egyszálú konfor- mációs polimorfizmus; TP53 = tumorprotein- 53 ; TRX = (total body resistance exercise) teljes testtel végzett ellenállásos edzés; WIFl = WNT-gátló faktor-1

A modern orvostudomány számára egyre inkább szükségessé válik olyan diagnosztikai módszerek fejlesztése és alkalmazása, amelyek a lehető legkisebb traumát okozzák a pácienseknek, mégis a legtöbb információhoz juttatják az orvost. A daganatos megbetegedések incidenciájának és mortalitásának növekedése, továbbá a gyulladásos kórfolyamatok gyakori előfordulása egyaránt felhívja a figyelmet a patológiás állapotok időben történő felismerésének jelentőségére. Számos kutatás irányul olyan biomarkerek azonosítására, amelyek minimálisan invazív beavatkozásokkal, megfelelő érzékenységgel és az adott elváltozásra specifikusan jelzik a kórfolyamat előrehaladottságának fokát. Napjainkban kerültek előtérbe az úgynevezett „folyadékbiopszia” (liquid biopsy), ezen belül is a véralapú szűrési technikák. Ezek az eljárások a véráramban keringő szabad nukleinsavak elemzését tüzik ki célul. Jelen közlemény a sejten kívüli DNS (skDNS) mennyiségi és minőségi jellemzőit, funkcióit és a vastagbéldaganatok diagnosztizálásában és szürésében rejlő lehetőségeit foglalja össze.

\section{A keringő szabad DNS felfedezése}

Mandel és Métais voltak az elsők, akiknek sikerült keringő szabad nukleinsavakat azonosítaniuk 1948-ban [1]. Megfigyelték, hogy egészséges és különböző betegségekben szenvedő emberekben extracellulárisan is találhatók nukleinsavak a vérben. Később szisztémás lupus erythematosusban (SLE) szenvedő páciensek vérében DNS ellen termelődő ellenanyagokat detektáltak, valamint Tan és mtsai a betegek szabadon keringő DNSében abnormális mintázatot figyeltek meg [2]. További kísérletek során 1977-ben Leon és mtsai szabad, sejten kívüli DNS-t (skDNS) mutattak ki tüdődaganatos bete- 
gek plazmájában, és radioimmunoassay módszerrel a DNS mennyiségét is mérni tudták [3]. A késóbbiekben kimutatták, hogy a tumoros betegek vérkeringésében található skDNS-molekulák neoplasztikus tulajdonságokkal jellemezhetők, ami arra utal, hogy DNS-molekulák a daganat szövetéból is bekerülhetnek a véráramba [4]. Az skDNS szintjének, valamint minőségi jellemzőinek változása a daganatos megbetegedéseken kívül számos egyéb kórfolyamatban megfigyelhető, többek között a gyulladásos megbetegedésekben, szepszisben, valamint akut stroke vagy atherosclerosis esetén is.

\section{A szabad DNS eredete és formája}

A DNS-keringésben való megjelenésére három fó mechanizmust ismerünk: az apoptózist, a nekrózist, illetve a direkt szekréciót, amely daganatos betegek esetén az egészséges és rákos sejtekből is történhet [5] (1. ábra). Egészséges egyénekben az apoptotikus sejtekből történő kiáramlást tartják a cirkuláló szabad DNS fő forrásának, azonban tumoros betegekben a proliferáló sejtek apoptotizáló képessége megszúnik, ezért az emelkedett szabad-DNS-szint feltehetően nem a programozott sejtha- lálon átesett sejtekből kiáramló DNS-nek köszönhető [6]. Daganat jelenléte esetén a nekrotizáló sejteket bekebelező makrofágok nagy mennyiségú DNS-t ürítenek környezetükbe, valamint bizonyított, hogy a vérben keringő lymphocyták in vitro spontán képesek DNS-kibocsátásra, ami felveti a szabad DNS aktív felszabadulásának lehetôségét [7]. Ezek mellett új generációs szekvenálással nem humán eredetű DNS-szekvenciákat is kimutattak a véráramban, amelyek elsősorban a szervezetünkben található mikrobákból, illetve az elfogyasztott táplálékból kerülnek a keringési rendszerbe $[8,9]$.

Számos hipotézis látott napvilágot a szabad DNS formáját illetően. A véráramban egy- és kétszálú DNS-molekulák is megtalálhatók, hosszuk 100 bp és 10 kbp között váltakozik [6]. Fragmentumelemzések rávilágítottak arra is, hogy az skDNS mérete jellemzően 180 bp és annak egész számú többszöröse [10]. Ez azzal magyarázható, hogy a nukleoszómákat megközelítőleg ekkora DNS alkotja, így a köztük lévő linker-DNS-szakaszon történő, nukleázok általi emésztés speciális fragmensmintázatot eredményez. A DNS-szakaszok méret szerinti eloszlásának megjelenése eltérhet a különböző betegcsoportokban, ami - többek között - mikrokapilláris-

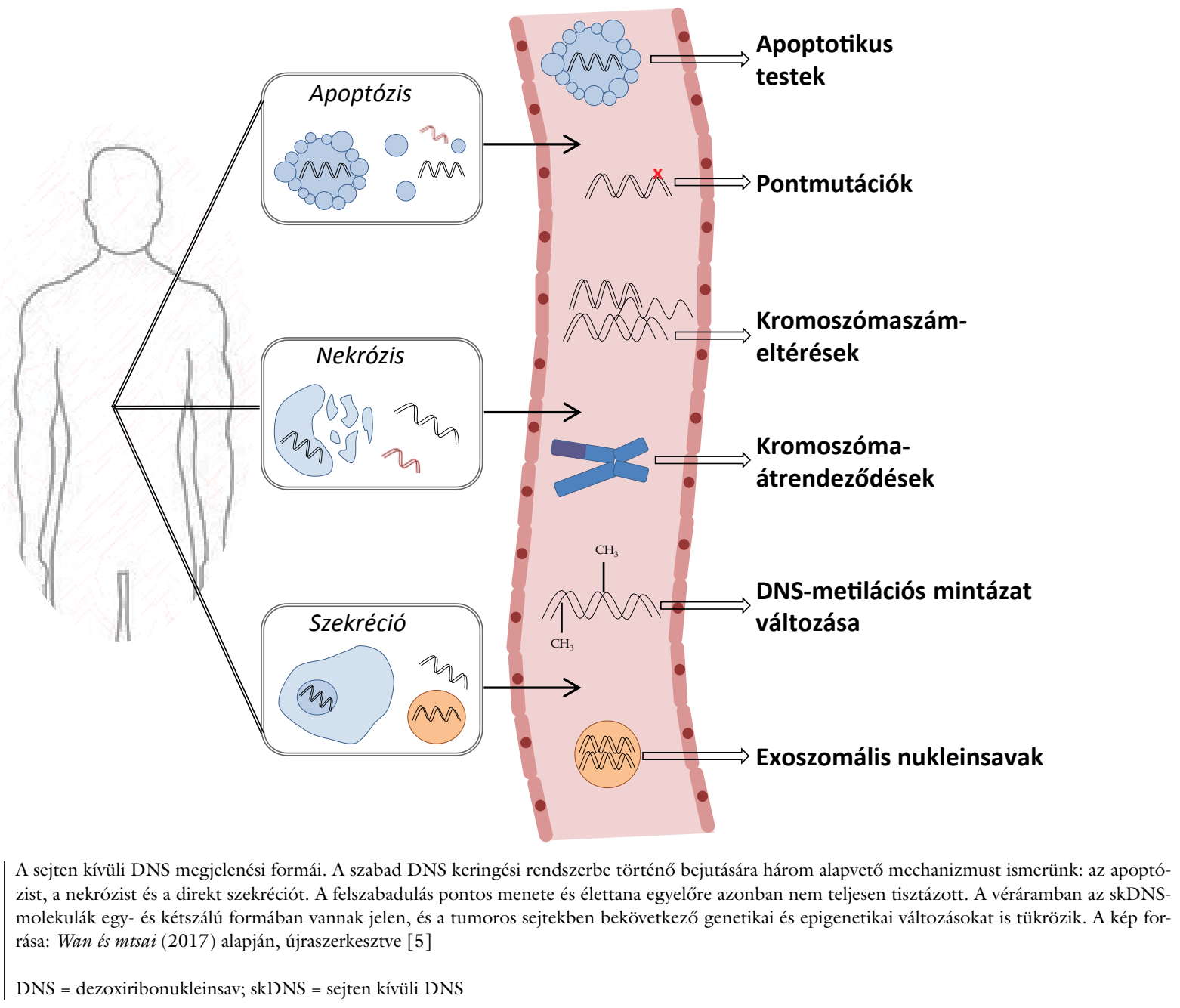



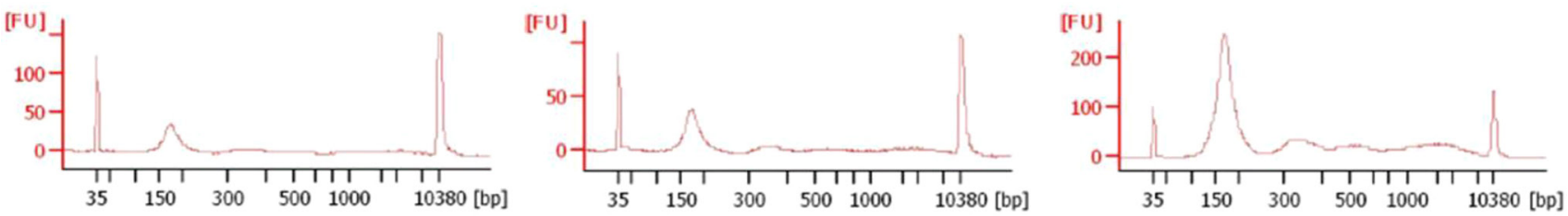

2. ábra

A szabad DNS méret szerinti eloszlása különböző betegcsoportokban. A sejten kívüli DNS egészséges mintákban jellemzően röved fragmentumokként van jelen a keringésben, míg a daganatos elváltozásokban a hosszabb szakaszok is megjelennek amellett, hogy a rövid szakaszok is nagy mennyiségben jelen vannak (Agilent BioAnalyzer 2100 [Santa Clara, CA, USA] készülékkel mérve)

$\mathrm{CRC}=$ vastagbélrák; DNS $=$ dezoxiribonukleinsav

elektroforézissel is vizsgálható (2. ábra). Egészségesekben jellemzően az alacsonyabb tartományban mozog az skDNS-fragmentumok hossza, míg adenomás és carcinomás mintákban a hosszabb skDNS-szakaszok is nagyobb mennyiségben vannak jelen, ami feltételezhetően a rákos betegekben megfigyelt csökkent DNáz-enzimaktivitásnak is köszönhető [11].

A keringésben lévő DNS önállóan, nukleoszóma részeként vagy esetlegesen más struktúrákhoz kötve is megtalálható, mint amilyenek a szállítófehérjék vagy az anti-DNS-antitestek [6]. Az utóbbi évtizedekben egyre inkább a kutatások fókuszába kerültek a microvesiculák, amelyek egy vagy több lipidmembránnal körülvett, különféle sejtalkotó elemeket és molekulákat tartalmazó partikulák (exoszómák, apoptotikus testek és egyéb microvesiculák). Számuk a daganatos betegek vérében magasabb az egészségesekéhez képest, és - megfigyelések szerint - ezek a microvesiculák daganat esetén a tumoros sejtek DNS-ét is tartalmazzák [12]. Sikerült igazolni, hogy a 30-100 nm-es mérettartományba eső exoszómákban található kettős szálú DNS két formában létezik: az egyik nagyobb méretű (>2,5 kbp) és az exoszóma membránjához kötődik, míg a kisebb (100bp-2,5kbp) a vesiculák belsejében található. Az exoszómákon kívül más microvesiculák is hordoznak DNS-molekulákat, mint például az apoptotikus testek, amelyek az apoptózis során lebomlott DNS-t tartalmazzák, és a partikulán belül védettek a DNáz enzimekkel szemben. A szabad DNS egyik megjelenési formájaként tarják számon a virtoszómát is, amely egy DNS/RNS lipoprotein komplex. Szabályozott módon szabadul fel élő sejtekből, és más sejtekbe bekerülve immunológiai változásokat vagy akár malignus transzformációt is előidézhet [13].

A szabad DNS féléletideje rövid, körülbelül 15 perc és néhány óra közé tehető [14], ezért szükségessé vált olyan vérvételi csövek fejlesztése, amelyek képesek megőrizni az skDNS stabilitását. Az elsők között a Streck cég (La Vista, NE, Amerikai Egyesült Államok [USA]) által forgalmazott Cell-Free DNA BCT ${ }^{\circledR}$ vérvételi csövek kerültek forgalomba, amelyek formaldehidmentes tartósítóreagenseket tartalmaznak, és ennek köszönhetően a szabad DNS akár 14 napig intakt marad szobahőmérsék- leten tárolt vérmintákban [15]. A reagensek képesek megakadályozni az skDNS nukleázok általi lebontását, továbbá gátolják a genomiális DNS kijutását a vér alakos elemeiből. Kang és mtsai egy összehasonlító vizsgálat során emlőrákos betegektől gyújtöttek vért standard K3EDTA (Greiner Bio-One International $\mathrm{GmbH}$, Kremsmünster, Ausztria), Streck- és CellSave (CellSearch; Menarini Silicon Biosystems Inc., Huntington Valley, PA, USA) csövekbe [16]. A mintákat $4{ }^{\circ} \mathrm{C}$-on és szobahőmérsékleten tárolták 2, 6 és 48 órán keresztül, majd plazmát szeparáltak, és megmérték a kivont szabad DNS mennyiségét. Megállapításuk szerint az skDNS 6 órával a gyưjtés után még stabil marad a gyüjtőcső típusától függetlenül, hosszú ideig tartó tárolás esetén azonban javaslatuk szerint a Streck-csövek használata előnyösebb volt. Munkacsoportunk 5 adenomás (AD) és 5 vastagbélrákos beteg plazmamintáin végzett hasonló vizsgálatokat, megfigyeléseink szerint azonban a gyüjtőcső típusa nem befolyásolja jelentősen az skDNS menynyiségét, hiszen 10 mintából 6 esetében tapasztaltunk magasabb DNS-szintet a Streck-csövek használatát követően a standard K3EDTA csövekkel szemben [17].

\section{A szabad DNS mennyiségi jellemzői és lehetséges funkciói}

Az skDNS szintje tág határok között változhat, azonban általánosságban elmondható, hogy míg az egészséges szervezetekben alacsonyabb (10-20 $\mathrm{ng} / \mathrm{ml})$, addig egyes gyulladással járó, traumás, autoimmun vagy fertőzéses kórállapotok esetén emelkedett mennyiséget mutat [18]. A daganatok közül magas szabad-DNS-mennyiség észlelhető például vastagbél-, emlő-, prosztata-, hasnyálmirigy- és tüdőrák esetén is [5]. Különbség figyelhető meg továbbá a plazma- és szérumminták szabad-DNSszintje között is. CRC esetén egyes tanulmányok körülbelül 20 és $200 \mathrm{ng} / \mathrm{ml}$ közötti skDNS-t mértek a plazmamintákban, míg szérumban akár $800 \mathrm{ng} / \mathrm{ml}$ értéket is mutathat az skDNS koncentrációja $[19,20]$. Ezeken kívül különböző fiziológiás folyamatokban - mint az erőteljes fizikai aktivitás, terhesség vagy az öregedés - szintén magas skDNS-koncentrációt figyelhetünk meg. 


\section{Sport és fizikai aktivitás}

A sportolás következtében megnövekedett skDNS-koncentrációt számos tanulmányban vizsgálták. Megerőltető testmozgáskor oxidatív és mechanikai stresszfolyamatok játszódnak le a szervezetben, amelyek a leukocyták és az izomsejtek sérüléséhez, valamint akutfázis-válaszhoz vezetnek. Hasonló folyamatok történnek fertőzések vagy különböző traumák következtében is, amelyek esetében emelkedett skDNS-koncentrációt figyeltek meg, csakúgy, mint különböző fizikai feladatok elvégzése után. A fiziológiás skDNS-szinthez képest mennyiségi növekedést tapasztaltak többek között félmaraton, ultramaraton, illetve TRX- (total body resistance exercise) gyakorlatokat követően [21, 22]. A sportolás során a plazmába kerülő szabad DNS egyik fó forrása valószínúleg a neutrophil granulocyták aktivitása során felszabaduló extracelluláris csapdák, azaz a NET-ek (neutrophil extracellular traps). A NET-ek ugyanis nemcsak az antimikrobiális védelemben vesznek rész, hanem a szervezetben lezajló steril gyulladásokban is, mint amilyeneket a fizikai aktivitás is eredményezhet. Ezt az is bizonyítja, hogy sportolók véréből készített perifériás keneten dezintegrált neutrophil granulocyták láthatók dekondenzált kromatinstruktúrával. Immunhisztokémiai festéssel szintén láthatóvá tehetők a látszólag intakt, ámde megduzzadt magvú neutrophil granulocyták és a körülöttük elhelyezkedő, magfestéssel megjelenített finom DNS-struktúra [23]. A fenti hipotézist tovább erôsítette az a tény is, hogy az aktivitás után gyüjtött plazmában a szabad DNS szintjének emelkedése egyedül a mieloperoxidáz enzim (MPO) szintjével korrelált, amely a neutrophil granulocyták specifikus granulumaiból szabadul ki [23].

\section{Várandósság}

Magzati szabad-DNS-molekulákat az anya keringési rendszerében 1997-ben figyeltek meg először [24]. Számos magzati kromoszóma-rendellenesség, valamint a terhesség során fellépő különböző komplikációk is befolyásolják a cirkuláló DNS mennyiségét. Emelkedett skDNS-szintet mértek a magzat 21-es és 13-as kromoszómájának triszómiája esetén, vészes terhességi hányáskor (hyperemesis gravidarum), kórosan nagy mennyiségú magzatvíz (polyhydramnion), rendellenesen tapadó placenta, praeeclampsia, illetve HELLP-szindróma (hemolízissel, emelkedett májenzimértékekkel és alacsony vérlemezkeszámmal járó szindróma) esetén is [25]. A magzati szabad DNS vizsgálata segítséget nyújthat ezen kórállapotok diagnosztizálásában, valamint a magzat nemének és Rh-vércsoportjának meghatározásában is a terhesség korai szakaszában [26]. A magzati DNS eredetére vonatkozóan több elmélet is létezik, egyértelmú bizonyítékok azonban még nem kerültek közlésre. Feltételezik, hogy az elsődleges forrás a placenta lehet, de lehetséges, hogy az erythroid sejtekből is szabadulnak ki DNS-molekulák [25].

\section{Öregedés}

A szabad DNS mennyisége és minőségi jellemzői az életkor elörehaladásával is változhatnak. Jylhävä és mtsai a Finnországban zajló Vitality 90+ projektben részt vevő, 90 évnél idősebb férfiak és nők ( $n=144)$ szabad-DNSkoncentrációját vetették össze fiatal kontrollegyénekével $(\mathrm{n}=30)$ [27]. A teljes skDNS-mennyiség mellett meghatározták - többek között - a nem metilált szabad DNS, az RNáz P-t kódoló skDNS és az 'Alu' ismétlődő szekvenciák mennyiségét is, és mindegyik paraméter esetében emelkedett koncentrációt találtak az idős korcsoport mintáiban a kontrollokhoz viszonyítva $(\mathrm{p}<0,05)$. Egy másik tanulmány három korcsoportban (20-40 éves; 41-60 éves; $\geq 61$ éves) elemezte a cirkuláló DNS mennyiségét párosított plazma- és szérummintákban [18]. Szignifikánsan emelkedett skDNS-koncentrációt csak a 60 évnél idősebb nőkben tapasztaltak a többi csoporthoz képest $(\mathrm{p}<0,05)$. Megállapították továbbá, hogy szérummintákban magasabb az skDNS szintje a plazmákhoz viszonyítva, valamint leírták, hogy a nem és a gyakori véradás sem befolyásolja az skDNS mennyiségét.

\section{Stressz-szignál}

A sejtek az őket ért károsító behatásokra különböző stressz-szignálokat bocsátanak ki. Megfigyelések szerint egy sejtkultúrán belül a sugárral kezelt sejtek információt adnak át a nem besugarazott sejteknek, amit „bystandereffektusnak” (BE) neveznek, és amely folyamat többek között a sejthalál, a genominstabilitás és a sejtek adaptív válaszreakciói során is megfigyelhető [28]. A sejtek közötti jelátvitel mechanizmusára több lehetőséget is ismerünk. Újabb hipotézisek szerint a bystandereffektus során a szabad DNS oxidációjának szerepe is fontos lehet a besugarazott és az ép sejtek közötti jelátvitelben. A feltevés onnan eredeztethető, hogy kísérletesen igazolták, hogy a magas oxidatív stressznek kitett páciensek plazmájából izolált szabad DNS szignifikánsan megváltoztatja a normális sejtek fiziológiás állapotát [28]. Egy másik tanulmányban megfigyelték, hogy akut myocardialis infarctuson átesett betegekből kinyert skDNS-sel kezelt patkányban a neonatalis szívizomsejtek összehúzódásának ereje és frekvenciája csökkent [29]. Leírták továbbá, hogy szignifikánsan csökkent azoknak a humán köldökvéna-endothelsejtek (HUVEC) tenyészetéből származó sejtek a nitrogén-monoxid-tartalma, amelyeket olyan páciensek plazmájából izolált szabad DNS-sel kezeltek, akiknek magas vérnyomása és érelmeszesedése volt [30]. A fenti kísérletek alapján feltételezhető, hogy a szabad DNS - mint szolúbilis stressz-szignál - számos patológiás folyamatban játszik szerepet.

\section{Thrombusképzés}

A keringő szabad DNS-sel kapcsolatos kutatások rávilágítottak arra, hogy a szabad DNS nem csupán inert, 
inaktív molekulaként van jelen a keringésben, hanem fontos biológiai aktivitással is rendelkezhet. Megfigyelések szerint az előzőekben már említett - neutrophil granulocyták által kibocsátott - NET-ek amellett, hogy fontos szerepet játszanak a baktériumok és gombák elleni védekezésben, olyan felületet biztosítanak, amely hozzájárulhat a thrombusképződéshez is [31]. A NET-mediált thrombusképződésben több mechanizmus is részt vesz. Egyrészt a thrombocyták képesek összekapcsolódni a neutrophil granulocytákkal, ezáltal stimulálják a gyors NET- és microthrombus-képződést, továbbá az extracelluláris kromatin, illetve a nukleoszómák DNS-molekulái képesek beindítani a véralvadási kaszkád intrinsik útját [31]. Emellett olyan másodlagos szerkezettel rendelkeznek, amely kötőhelyet biztosít a koagulációs kaszkád fehérjéi számára, ezzel aktiválva őket [32]. A szabad DNSés a NET-mediált thrombusképződést nemcsak az artériás, hanem a vénás oldalon is megfigyelték: különböző állatkísérletekben sikerült kimutatni, hogy a NETekből felszabaduló skDNS aktiválja a thrombocytákat és a szöveti faktort, ezenkívül az idegen felszín indukálta koagulációban is fontos szerepe van [33].

\section{A szabad DNS mennyiségi és minőségi változásainak elemzésére alkalmas technikák}

Az skDNS izolálása a DNS alacsony mennyisége és töredezettsége (fragmentáltsága) miatt technikai kihívások elé állítja a kutatókat. Számos, kereskedelmi forgalomban kapható, DNS-kivonásra alkalmas kit közül választ- hatunk, amelyek alapvetően két módon képesek megkötni a DNS-molekulákat: mágneses gyöngy felszínén vagy szilikagél-alapú membránon [34]. Az utóbbi években a kézi módszerek mellett automata skDNS-izolálási rendszerek is elérhetővé váltak, amelyeknek köszönhetően párhuzamosan, standardizált körülmények között lehet nagyszámú plazmamintából DNS-t kinyerni, ami fontos szempont a diagnosztikai és prognosztikai tesztek fejlesztésénél is. Lényeges azonban kiemelni, hogy a különböző DNS-extrakciós módszerek befolyásolhatják a további vizsgálatok eredményeit, így többek között a metilációs mintázat detektálására is hatással lehetnek [17]. A szabad-DNS-mennyiség meghatározásának széleskörüen alkalmazott technikái közé tartoznak a fluorimetriás és a PCR-alapú mérések. Az skDNS szintjének kvantifikálása mellett azonban a DNS minőségi jellemzőinek vizsgálata is fontos. Az skDNS genetikai, illetve epigenetikai mintázatának elemzésére számos módszer áll rendelkezésünkre. A mutációk elemzésére használhatunk különböző PCR-technikákat (például digitális PCR-t), denaturáló nagy hatékonyságú folyadékkromatográfiát (DHPLC) vagy enzimhez kapcsolt immunszorbensteszteket (ELISA), továbbá nagy áteresztőképességú módszereket is, mint az array-vizsgálatok vagy az új generációs szekvenálás (NGS) [35]. A leginkább kutatott epigenetikai módosulás a DNS-metiláció, amelyet tanulmányozhatunk teljesgenom-szinten vagy célzottan, az adott génekhez tartozó promóter régiókban is. A technikákat csoportosíthatjuk aszerint, hogy enzimatikus emésztést, affinitásalapú dúsítást vagy biszulfitkonverziós kezelést alkalmaznak. A teljesgenom-szintű DNS-metilációs változásokat kimutathatjuk - egyebek

1. táblázat |A CRC-s páciensek skDNS-frakciójában megfigyelt jelentősebb mutációk

\begin{tabular}{|c|c|c|c|c|c|c|}
\hline A gén neve & Mintatípus & $\begin{array}{l}\text { A kontrollminták } \\
\text { száma }\end{array}$ & $\begin{array}{l}\text { A CRC-minták } \\
\text { száma }\end{array}$ & $\begin{array}{l}\text { Mutáció előfordulása } \\
\text { CRC-mintákban }\end{array}$ & Az alkalmazott módszer & Referencia \\
\hline$A P C$ & Szérum & 50 & 104 & $14(13,5 \%)$ & PCR-SSCP & {$[41]$} \\
\hline$A P C$ & Plazma & 21 & 22 & $16(72,7 \%)$ & BEAMing & {$[43]$} \\
\hline$B R A F$ & Plazma & - & 97 & $5(5,2 \%)$ & Allélspecifikus PCR & [45] \\
\hline$B R A F$ & Plazma & - & 503 & $17(3,4 \%)$ & BEAMing & [34] \\
\hline$K R A S$ & Szérum & - & 44 & $3(6,8 \%)$ & $\begin{array}{l}\text { Oligonukleotidligatiós } \\
\text { teszt }\end{array}$ & {$[40]$} \\
\hline KRAS & Szérum & 50 & 104 & $16(15,4 \%)$ & PCR-SSCP & [41] \\
\hline KRAS & Plazma & - & 106 & $33(31,1 \%)$ & PNA-PCR & [42] \\
\hline$K R A S$ & Szérum & - & 78 & $32(41 \%)$ & PCR & [44] \\
\hline$K R A S$ & Plazma & - & 97 & $38(39,2 \%)$ & Allélspecifikus PCR & [45] \\
\hline$K R A S$ & Plazma & - & 115 & $59(51,3 \%)$ & BEAMing & {$[46]$} \\
\hline KRAS & Plazma & - & 503 & $349(69,4 \%)$ & BEAMing & [34] \\
\hline TP53 & Szérum & - & 44 & $7(15,9 \%)$ & $\begin{array}{l}\text { Oligonukleotidligatiós } \\
\text { teszt }\end{array}$ & {$[40]$} \\
\hline TP53 & Szérum & 50 & 104 & $13(12,5 \%)$ & PCR-SSCP & {$[41]$} \\
\hline
\end{tabular}

CRC = vastagbélrák; SSCP = egyszálú konformációs polimorfizmus; PNA-PCR = peptid-nukleinsav polimeráz-láncreakció 
mellett - különböző metilációs array-k, biszulfitszekvenálás, metilált-DNS-immunprecipitáció (MeDIP) vagy methyl capture (MetCap) szekvenálás segítségével. Az előre kiválasztott gének metilációs státuszának meghatározására alkalmas technikák nagy része biszulfitkonverziós lépéssel indul. Idesorolhatjuk a metilációspecifikus és MethyLight PCR-t, a biszulfitspecifikus PCR-t követő nagy felbontású olvadáspont-elemzési, illetve a különböző szekvenálási módszereket (például Sangerszekvenálás, piroszekvenálás, NGS) [36].

\section{A szabad DNS mint diagnosztikai marker vastagbélrák esetén}

A vastagbélrák (CRC) az egyik leggyakoribb daganatos megbetegedés világszerte, mind a férfiak, mind a nók körében. 2018-ban Európában 772000 újonnan diagnosztizált eset és 242000 haláleset kötődött a CRC-hez [37]. Magyarországon az incidenciája és a halálozási aránya is folyamatosan emelkedik; évente körülbelül 10000 új beteget diagnosztizálnak, és 5000 haláleset következik be a vastagbélrák miatt. A diagnózis mihamarabbi felállí- tása nagymértékben növeli a betegek túlélési esélyeit, hiszen korai stádiumban (Dukes A) az ötéves túlélési arány 90\%-os, míg előrehaladott fázisban, távoli szervi áttét esetén csupán $5 \%$ alatti [37]. Ezek az adatok is alátámasztják, hogy szükséges a szürőmódszerek folyamatos fejlesztése, amelyek közé a szabad-DNS-frakció elemzését célzó minimálisan invazív, vérvételalapú vizsgálatok is sorolhatók. A CRC kialakulását az egészséges vastagbélnyálkahártyasejtekben bekövetkező molekuláris biológiai elváltozások indukálják, amelyek közé a különböző genetikai, illetve epigenetikai módosításokat sorolhatjuk, és amelyek a keringési rendszerbe kerülő szabad-DNSfrakciónak köszönhetően plazma- és szérummintákban is elemezhetők [35]. A következőkben bemutatjuk a vastagbéldaganatok kialakulása során leggyakrabban előforduló mutációs és DNS-metilációs elváltozásokat (1. és 2. táblázat). Kutatócsoportunk korábbi vizsgálata szerint a metilált-DNS-fragmentumok stabilabbak a véráramban, mint a nem-metilált-DNS-szakaszok [38], ezért - egyebek mellett - ez is magyarázhatja, hogy a rákos mintákban nagyobb arányban fordulnak elő a DNS-metilációs elváltozások (65-100\%), mint a mutációk (5-75\%).

2. táblázat |Az skDNS-frakcióban megfigyelt jelentősebb DNS-metilációs változást mutató gének adenoma és CRC esetén

\begin{tabular}{|c|c|c|c|c|c|c|c|c|c|c|}
\hline A gén neve & Mintatípus & $\begin{array}{l}\text { A kontroll- } \\
\text { minták } \\
\text { száma }\end{array}$ & $\begin{array}{l}\text { Az AD- } \\
\text { minták } \\
\text { száma }\end{array}$ & $\begin{array}{l}\text { A metilált } \\
\text { AD-minták } \\
\text { száma }(\%)\end{array}$ & $\begin{array}{l}\text { Szenzitivitás } \\
\text { és specificitás } \\
\text { AD }\end{array}$ & $\begin{array}{l}\text { A } \\
\text { CRC-min- } \\
\text { ták száma }\end{array}$ & $\begin{array}{l}\text { A metilált } \\
\text { CRC-minták } \\
\text { száma }(\%)\end{array}$ & $\begin{array}{l}\text { Szenzitivitás } \\
\text { és specificitás } \\
\text { CRC }\end{array}$ & $\begin{array}{l}\text { Az alkalmazott } \\
\text { módszer }\end{array}$ & Referencia \\
\hline $\begin{array}{l}\text { FHIT } \\
\text { APC } \\
\text { SMAD4 } \\
\text { E-cad } \\
D A P K 1\end{array}$ & Plazma & 60 & 40 & NA & NA & 60 & NA & $\begin{array}{l}50 \% \text { és } 85 \% \\
57 \% \text { és } 86 \% \\
52 \% \text { és } 64 \% \\
60 \% \text { és } 84 \% \\
50 \% \text { és } 74 \%\end{array}$ & $\begin{array}{l}\text { Metilációspe- } \\
\text { cifikus PCR }\end{array}$ & {$[58]$} \\
\hline $\begin{array}{l}B C A T 1 \\
I K Z F 1\end{array}$ & Plazma & 144 & - & - & - & 74 & $\begin{array}{l}48(64,9 \%) \\
50(67,6 \%)\end{array}$ & $\begin{array}{l}77 \% \text { és } \\
92,4 \%\end{array}$ & $\begin{array}{l}\text { Metilációspe- } \\
\text { cifikus PCR }\end{array}$ & [59] \\
\hline $\begin{array}{l}B C A T 1 \\
I K Z F 1\end{array}$ & Plazma & 867 & 448 & $41(9,2 \%)$ & NA & 66 & $41(62,1 \%)$ & $\begin{array}{l}62,1 \% \text { és } \\
91,8 \%\end{array}$ & $\begin{array}{l}\text { Multiplex } \\
\text { RT-PCR }\end{array}$ & {$[60]$} \\
\hline \multirow[t]{2}{*}{$\begin{array}{l}\text { NPY } \\
P E N K \\
W I F 1\end{array}$} & Szérum & 30 & 10 & NA & NA & 9 & $9(100 \%)$ & $100 \%$ és $73 \%$ & $\begin{array}{l}\text { Metilációspe- } \\
\text { cifikus PCR, } \\
\text { Biszulfitszek- } \\
\text { venálás }\end{array}$ & {$[61]$} \\
\hline & & 131 & 16 & & & 23 & $21(91,3 \%)$ & $91 \%$ és $25 \%$ & & \\
\hline $\begin{array}{l}\text { SFRP1 } \\
\text { SFRP2 } \\
\text { SDC2 } \\
\text { PRIMA1 }\end{array}$ & Plazma & 37 & 37 & $\begin{array}{l}33(89,2 \%) \\
31(83,8 \%) \\
30(81,1 \%) \\
26(70,3 \%)\end{array}$ & $\begin{array}{l}89,2 \% \text { és } \\
86,5 \%\end{array}$ & 47 & $\begin{array}{l}40(85,1 \%) \\
34(72,3 \%) \\
42(89,4 \%) \\
38(80,9 \%)\end{array}$ & $\begin{array}{l}91,5 \% \text { és } \\
97,3 \%\end{array}$ & $\begin{array}{l}\text { MethyLight } \\
\text { PCR }\end{array}$ & {$[62]$} \\
\hline SEPTQ & Plazma & $\frac{172}{155}$ & - & - & - & $\frac{97}{90}$ & $\frac{55(56,7 \%)}{50(55,6 \%)}$ & $\begin{array}{l}57 \% \text { és } 98 \% \\
56 \% \text { és } 95 \%\end{array}$ & RT-PCR & [49] \\
\hline SEPTP & Plazma & 33 & 94 & $27(28,7 \%)$ & NA & 33 & $24(72,7 \%)$ & NA & RT-PCR & {$[50]$} \\
\hline SEPT9 & Plazma & 92 & - & - & - & 92 & $73(79,3 \%)$ & $79 \%$ és $99 \%$ & RT-PCR & {$[51]$} \\
\hline SEPTP & Plazma & 193 & - & - & - & 97 & $70(72,2 \%)$ & $72 \%$ és $81 \%$ & RT-PCR & {$[55]$} \\
\hline \multirow[t]{2}{*}{$A L X 4$} & Szérum & 30 & - & - & - & 30 & $25(83,3 \%)$ & $83 \%$ és $70 \%$ & $\begin{array}{l}\text { MethyLight } \\
\text { PCR }\end{array}$ & {$[56]$} \\
\hline & Plazma & 22 & 36 & $16(44,4 \%)$ & $44 \%$ és $82 \%$ & - & - & - & & \\
\hline
\end{tabular}

$\mathrm{AD}=$ adenoma $; \mathrm{CRC}=$ vastabélrák $; \mathrm{NA}=$ nincs adat RT-PCR = valós idejű polimeráz-láncreakció 


\section{DNS-mutációk elemzése a szabad-DNS-frakcióban}

A vastagbélrák kialakulásához számos mutáció felhalmozódása, például az APC-, a TP53-, a KRAS- és a BRAFgénekben történő változások járulnak hozzá. Ezek a mutációk a vastagbél szövetében nagy arányban megjelennek a daganat fejlődése során, azonban plazma- és szérummintákban eltér a kimutathatóságuk [39] (1. táblázat). Számos tanulmányban leírták, hogy előrehaladott stádiumokban a mutációkat magas érzékenységgel lehet kimutatni a szabad-DNS-frakcióban, ami a daganat fejlödése során emelkedő skDNS-mennyiségnek köszönhető [40, 41]. Hibi és mtsai mutáns KRAS-gént csak a Dukes C- és D-stádiumú CRC-s betegek szérummintáiban detektáltak, a betegség korai szakaszában nem figyeltek meg mutációt [40]. Az APC-, a TP53-és a KRAS-gén mutációi összefüggésbe hozhatók a nyirokcsomóáttétek megjelenésével, a daganat kiújulásával, valamint rossz prognózist is jelezhetnek [41-43]. A mutáns KRAS-, $N R A S$ - és $B R A F$-génnek az skDNS-frakcióban történő kimutatása a CRC prognózisának meghatározására és a terápia monitorozására is használható [34, 41, 44-46]. Messaoudi és mtsai a BRAF- (V600E) és a KRAS-gén elemzése során megállapították, hogy a magas mutáns szabad-DNS-koncentráció és a megnövekedett mutációs terhelés (a teljes skDNS-ben lévő mutáns allélok százalékos aránya) áttétes CRC-s páciensekben szignifikánsan csökkenti a túlélési arányt [45]. Egy másik munkacsoport MassDetect CRC-panel (Sequenom) segítségével 74, CRC-hez kapcsolt gén 155 mutációját vizsgálta, és megállapították, hogy az 5 éves túlélés szignifikánsan alacsonyabb azokban a betegekben, akikben megtalálhatók a mutációk (48\%), a mutációkat nem hordozókkal szemben $(77 \%)$ [47].

\section{A cirkuláló DNS metilációs mintázata}

A DNS-t érintő metiláció az egyik leglényegesebb epigenetikai módosulás. A folyamat során egy metilcsoport kapcsolódik a DNS citozinbázisához a citozin-guanindinukleotid (CpG)-helyeken. A CpG-gazdag DNS-régiókat CpG-szigeteknek nevezzük (a CpG dinukleotidok legalább 60\%-os arányban vannak jelen), amelyek gyakran a gének promóter régióiban találhatók. Az itt előforduló fokozott DNS-metiláció jellemzően befolyásolja a gének átíródását, hiszen a metilcsoport gátolja egyes transzkripciós faktorok kötődését, valamint olyan változásokat indukál a kromatin szerkezetében, amelyek végül a transzkripció csökkenéséhez vagy teljes gátlásához vezethetnek [48]. Az aberráns metilációs mintázatot mutató gének ígéretes biomarkerként szolgálhatnak, hiszen - csakúgy, mint a mutációk - a szöveti minták mellett a perifériás vérben is vizsgálhatók a szabad-DNSfrakciónak köszönhetően. Egyes tanulmányok egy-egy marker azonosítását tűzték ki célul, míg mások több metilációs markert tartalmazó panelt állítottak össze (2. táb- lázat). Az Epi proColon 2.0 teszt (Epigenomics AG, Berlin, Németország) az egyik legismertebb, FDA-engedéllyel (Food and Drug Administration) rendelkező vastagbélrák-specifikus véralapú szürőteszt, amely a septin-9 ( SEPT9)-gén metiláltsági fokát méri. A kvantitatív valós idejü PCR módszert alkalmazó teszt érzékenysége 6575\%, míg specificitása 80-95\% közé esik, és elsősorban a CRC késôi stádiumaiban mutat pozitivitást [49-51]. Munkacsoportunk a teszt kifejlesztésében és tesztelésében is részt vett, amelynek eredményeiról több közleményben is beszámoltunk [51-54]. Johnson és mtsai a klinikai gyakorlatban alkalmazott FIT (immunalapú székletvér-vizsgálat - fecal immunochemical test) teszttel vetették össze az Epi proColon 2.0 teszt érzékenységét 97 CRC-s és 193 kontrollmintában [55]. A rákos minták 72,2\%-a bizonyult septin-9-pozitívnak 80,8\%-os specificitás mellett, míg a FIT teszt kissé alacsonyabb szenzitivitást (68\%) jelzett 97,4\%-os specificitásértékkel. A FIT és az Epi proColon 2.0 tesztről is elmondható, hogy adenomás esetek kimutatására kevésbé érzékenyek [55]. A SEPT9-gén mellett egyéb ígéretes DNS-metilációs markerek is ismertek a szakirodalomban. Az $A L X 4$ gén által kódolt fehérje a Wnt/ $\beta$-katenin jelátviteli útvonal bizonyos elemeinek aktivitását szabályozza, és kifejeződése kismértékű a vastagbélrákos betegek szöveti mintáiban. Az $A L X 4$ promóter fokozott metilációját CRC mellett nyelőcső-, epevezeték-, hasnyálmirigy- és gyomorrák esetén is megfigyelték [56,57]. Ebert és mtsai szérumminták elemzésével $83,3 \%$-os szenzitivitással és 70\%-os specificitással tudták elkülöníteni a CRC-s betegeket a kontrolloktól [56]. Egy másik tanulmány a CRC kialakulásában szerepet játszó $F H I T, A P C, S M A D 4, E-$ cad és $D A P K 1$ gének metilációs mintázatát adenomás és CRC-s betegek plazmamintáiban elemezte [58]. Mind az öt marker szignifikánsan magasabb metilációs szintet mutatott a rákos betegek plazmáiban a rosszindulatú daganattal nem rendelkező (egészséges és $\mathrm{AD}$ ) egyénekhez viszonyítva, az adenomás csoportban azonban nem találtak jelentős metilációsszint-emelkedést az egészséges kontrollokhoz képest. Az eredmények alapján megállapítható, hogy korai CRC-stádiumban (Dukes A) csak az $A P C$-gén promóterében fokozott a DNS-metiláció. A két legmegbízhatóbb markernek az E-cadherin és az $A P C$ mutatkozott $84 \%$-os és $86 \%$-os specificitásértékek mellett 60\%-os és 57\%-os érzékenységgel [58]. Pedersen és mtsai az IKZFI- és a BCATl-gént analizálták kvantitatív metilációspecifikus PCR-módszerrel vastagbélrákos $(\mathrm{n}=74)$ és egészséges $(\mathrm{n}=144)$ páciensek plazmamintáiban [59]. Vizsgálatukban a két markert kombinálva 77\%-os szenzitivitással és 92,4\%-os specificitással tudták elkülöníteni a CRC-mintákat a kontrolloktól. Egy másik kutatócsoport ugyanezeket a géneket 1381 mintában elemezte és vetette össze a FIT teszt érzékenységével [60]. A markerek együttesen 62,1\%-os érzékenységet mutattak a CRC-s, 16\%-osat az előrehaladott adenoma és 25\%-osat a korai adenoma stádiumú betegek mintáiban. A FIT teszt a rákos és a korai adenomás betegek 
esetében is kissé alacsonyabb értékeket jelzett (59,1\% és 7,2\%). Roperch és mtsai az NPY-, a PENK- és a WIF1gén metilációs státuszát 161 egészséges, 26 polipos és 32 CRC-s beteg szérummintáiban elemezték, és a CRCs mintákat 59\%-os érzékenységgel és 95\%-os specificitással azonosították [61]. Munkacsoportunk egy 4 gént (SFRP1, SFRP2, SDC2 és PRIMA1) tartalmazó panel metilációs állapotát vizsgálta egészséges, $\mathrm{AD}$ és CRC-betegek plazmamintáiban $(\mathrm{n}=121)$ [62]. A négy gént együttesen elemezve megállapítottuk, hogy legalább 3 marker emelkedett metilációs szintû a CRC-s minták 89\%-ában (42/47) és az adenomák 81\%-ában (30/37). A markerek metilációja továbbá folyamatos emelkedést mutatott az egészséges-vastagbél-adenoma-carcinoma szekvencia mentén. Látható tehát, hogy az ígéretes és nagy szenzitivitású markerek széles tárháza található a szakirodalomban, azonban jövőbeli diagnosztikai alkalmazásuk érdekében ezek nagy mintaszámon történő további vizsgálata és az eredmények validálása elengedhetetlen.

\section{Következtetés és kitekintés}

A vérben található keringő szabad-DNS-molekulák mennyiségi és minőségi változásainak, valamint lehetséges szerepének elemzése intenzíven kutatott tudományterület napjainkban. Jelen összefoglaló közleményünkben az skDNS általános jellemzőinek áttekintése mellett a szabad DNS izolálására és detektálására alkalmas technikák bemutatására, valamint különböző fiziológiás és patológiás folyamatokban betöltött szerepének ismertetésére törekedtünk. Rákos megbetegedések esetén a keringő DNS egyik forrása a tumorsejt-populációk, így a daganat DNS-ét érintő változások a plazma- és szérummintákban is nyomon követhetők. A vastagbélrák az egyik legnagyobb incidenciát és mortalitást mutató ráktípus, amelynek mielőbbi felismerése kulcsfontosságú a betegek kezelése szempontjából. A CRC kialakulása során megváltozott genetikai és epigenetikai mintázatok vérben történő elemzése lehetőséget kínál olyan folyadékbiopszia-alapú, minimálisan invazív, rákspecifikus szürési, diagnosztikai és prognosztikai tesztek kifejlesztésére, amelyek a rutin klinikai gyakorlat szerves részét képezhetik a jövőben.

Anyagi támogatás: A közlemény a Nemzeti Kutatási, Fejlesztési és Innovációs Hivatal (NVKP_16-1-20160004), továbbá a Nemzeti Erőforrás Minisztérium Felsőoktatási Intézményi Kiválósági Program támogatásával a molekuláris biológiai tematikus program keretén belül készült.

Szerzői munkamegosztás: B. B. K., M. E., M. B.: A kézirat megírása, a szakirodalom kutatása, válogatása és feldolgozása. Sz. K. A., K. A., G. O., N. Zs. B., Zs. S.:
A szakirodalom kutatása, a kézirat átolvasása. T. Zs., D. M., I. P, M. B.: A kézirat kritikus átolvasása. A cikk végleges változatát valamennyi szerző elolvasta és jóváhagyta.

Érdekeltségek: A szerzőknek nincsenek érdekeltségeik.

\section{Irodalom}

[1] Mandel P, Métais P. Les acides nucléiques du plasma sanguin chez l'homme. C R Seances Soc Biol Fil. 1948; 142: 241-243.

[2] Tan EM, Kunkel HG. Characteristics of a soluble nuclear antigen precipitating with sera of patients with systemic lupus erythematosus. J Immunol. 1966; 96: 464-471.

[3] Leon SA, Shapiro B, Sklaroff DM, et al. Free DNA in the serum of cancer patients and the effect of therapy. Cancer Res. 1977; 37: 646-650.

[4] Stroun M, Anker P, Maurice P, et al. Neoplastic characteristics of the DNA found in the plasma of cancer patients. Oncology 1989; 46: 318-322.

[5] Wan JC, Massie C, Garcia-Corbacho J, et al. Liquid biopsies come of age: towards implementation of circulating tumour DNA. Nat Rev Cancer 2017; 17: 223-238.

[6] van der Vaart M, Pretorius PJ. Circulating DNA. Its origin and fluctuation. Ann N Y Acad Sci. 2008; 1137: 18-26.

[7] Stroun M, Maurice P, Vasioukhin V, et al. The origin and mechanism of circulating DNA. Ann N Y Acad Sci. 2000; 906: 161168.

[8] Kowarsky M, Camunas-Soler J, Kertesz M, et al. Numerous uncharacterized and highly divergent microbes which colonize humans are revealed by circulating cell-free DNA. Proc Natl Acad Sci U S A 2017; 114: 9623-9628.

[9] Spisák S, Solymosi N, Ittzés P, et al. Complete genes may pass from food to human blood. PLoS ONE 2013; 8: e69805.

[10] Jiang P, Lo YM. The long and short of circulating cell-free DNA and the ins and outs of molecular diagnostics. Trends Genet. 2016; 32: 360-371.

[11] Tamkovich SN, Cherepanova AV, Kolesnikova EV, et al. Circulating DNA and DNase activity in human blood. Ann N Y Acad Sci. 2006; 1075: 191-196.

[12] Mouliere F, Thierry AR. The importance of examining the proportion of circulating DNA originating from tumor, microenvironment and normal cells in colorectal cancer patients. Expert Opin Biol Ther. 2012; 12(Suppl 1): S209-S215.

[13] Gahan PB, Stroun M. The virtosome - a novel cytosolic informative entity and intercellular messenger. Cell Biochem Funct. 2010; 28: 529-538.

[14] Hyun MH, Sung JS, Kang EJ, et al. Quantification of circulating cell-free DNA to predict patient survival in non-small-cell lung cancer. Oncotarget 2017; 8: 94417-94430.

[15] Medina Diaz I, Nocon A, Mehnert DH, et al. Performance of Streck cfDNA blood collection tubes for liquid biopsy testing. PLOS ONE 2016; 11: e0166354.

[16] Kang Q, Henry NL, Paoletti C, et al. Comparative analysis of circulating tumor DNA stability in $\mathrm{K}_{3}$ EDTA, Streck, and CellSave blood collection tubes. Clin Biochem. 2016; 49: 13541360 .

[17] Bartak BK, Kalmar A, Galamb O, et al. Blood collection and cellfree DNA isolation methods influence the sensitivity of liquid biopsy analysis for colorectal cancer detection. Pathol Oncol Res. 2018 Jan 27. doi: 10.1007/s12253-018-0382-z. [Epub ahead of print]

[18] Zhong XY, Hahn S, Kiefer V, et al. Is the quantity of circulatory cell-free DNA in human plasma and serum samples associated with gender, age and frequency of blood donations? Ann Hematol. 2007; 86: 139-143. 
[19] Mouliere F, El Messaoudi S, Pang D, et al. Multi-marker analysis of circulating cell-free DNA toward personalized medicine for colorectal cancer. Mol Oncol. 2014; 8: 927-941.

[20] Czeiger D, Shaked G, Eini H, et al. Measurement of circulating cell-free DNA levels by a new simple fluorescent test in patients with primary colorectal cancer. Am J Clin Pathol. 2011; 135: 264-270.

[21] Atamaniuk J, Stuhlmeier KM, Vidotto C, et al. Effects of ultramarathon on circulating DNA and mRNA expression of proand anti-apoptotic genes in mononuclear cells. Eur J Appl Physiol. 2008; 104: 711-717

[22] Atamaniuk J, Vidotto C, Kinzlbauer M, et al. Cell-free plasma DNA and purine nucleotide degradation markers following weightlifting exercise. Eur J Appl Physiol. 2010; 110: 695-701.

[23] Beiter T, Fragasso A, Hudemann J, et al. Neutrophils release extracellular DNA traps in response to exercise. J Appl Physiol (1985). 2014; 117: 325-333.

[24] Lo YM, Corbetta N, Chamberlain PF, et al. Presence of fetal DNA in maternal plasma and serum. Lancet 1997; 350: 485487.

[25] Wataganara T, Bianchi DW. Fetal cell-free nucleic acids in the maternal circulation: new clinical applications. Ann N Y Acad Sci. 2004; 1022: 90-99.

[26] Turner MJ, Martin CM, O'Leary JJ. Detection of fetal Rhesus D gene in whole blood of women booking for routine antenatal care. Eur J Obstet Gynecol Reprod Biol. 2003; 108: 29-32.

[27] Jylhävä J, Nevalainen T, Marttila S, et al. Characterization of the role of distinct plasma cell-free DNA species in age-associated inflammation and frailty. Aging Cell 2013; 12: 388-397.

[28] Ermakov AV, Konkova MS, Kostyuk SV, et al. Oxidized extracellular DNA as a stress signal in human cells. Oxid Med Cell Longev. 2013; 2013: 649747

[29] Bulicheva N, Fidelina O, Mkrtumova N, et al. Effect of cell-free DNA of patients with cardiomyopathy and rDNA on the frequency of contraction of electrically paced neonatal rat ventricular myocytes in culture. Ann N Y Acad Sci. 2008; 1137: 273277.

[30] Efremova LV, Alekseeva AY, Konkova MS, et al. Extracellular DNA affects NO content in human endothelial cells. Bull Exp Biol Med. 2010; 149: 196-200.

[31] Oehmcke S, Mörgelin M, Herwald H. Activation of the human contact system on neutrophil extracellular traps. J Innate Immun. 2009; 1: 225-230.

[32] Urban CF, Ermert D, Schmid M, et al. Neutrophil extracellular traps contain calprotectin, a cytosolic protein complex involved in host defense against Candida albicans. PLoS Pathog. 2009; 5 : el000639.

[33] Brill A, Fuchs TA, Savchenko AS, et al. Neutrophil extracellular traps promote deep vein thrombosis in mice. J Thromb Haemost. 2012; 10: 136-144.

[34] Xue X, Teare MD, Holen I, et al. Optimizing the yield and utility of circulating cell-free DNA from plasma and serum. Clin Chim Acta 2009; 404: 100-104.

[35] Tóth K, Barták BK, Tulassay Z, et al. Circulating cell-free nucleic acids as biomarkers in colorectal cancer screening and diagnosis. Expert Rev Mol Diagn. 2016; 16: 239-252.

[36] Kurdyukov S, Bullock M. DNA methylation analysis: choosing the right method. Biology 2016; 5: 3 .

[37] Ferlay J, Colombet M, Soerjomataram I, et al. Cancer incidence and mortality patterns in Europe: estimates for 40 countries and 25 major cancers in 2018. Eur J Cancer 2018; 103: 356-387.

[38] Barták BK, Nagy ZB, Spisák S, et al. In vivo analysis of circulating cell-free DNA release and degradation. [A sejten kívüli szabad DNS felszabadulásának és degradációjának in vivo elemzése.] Orv Hetil. 2018; 159: 223-233. [Hungarian]

[39] Kidess E, Heirich K, Wiggin M, et al. Mutation profiling of tumor DNA from plasma and tumor tissue of colorectal cancer patients with a novel, high-sensitivity multiplexed mutation detection platform. Oncotarget 2015; 6: 2549-2561.

[40] Hibi K, Robinson CR, Booker S, et al. Molecular detection of genetic alterations in the serum of colorectal cancer patients. Cancer Res. 1998; 58: 1405-1407.

[41] Wang JY, Hsieh JS, Chang MY, et al. Molecular detection of $A P C, K$-ras, and $p 53$ mutations in the serum of colorectal cancer patients as circulating biomarkers. World J Surg. 2004; 28: 721726.

[42] Bai YQ, Liu XJ, Wang Y, et al. Correlation analysis between abundance of K-ras mutation in plasma free DNA and its correlation with clinical outcome and prognosis in patients with metastatic colorectal cancer. Zhonghua Zhong Liu Za Zhi 2013; 35 : 666-671.

[43] Diehl F, Li M, Dressman D, et al. Detection and quantification of mutations in the plasma of patients with colorectal tumors. Proc Natl Acad Sci U S A 2005; 102: 16368-16373.

[44] Ryan BM, Lefort F, McManus R, et al. A prospective study of circulating mutant KRAS2 in the serum of patients with colorectal neoplasia: strong prognostic indicator in postoperative follow up. Gut 2003; 52: 101-108.

[45] El Messaoudi S, Mouliere F, Du Manoir S, et al. Circulating DNA as a strong multimarker prognostic tool for metastatic colorectal cancer patient management care. Clin Cancer Res. 2016; 22: 3067-3077.

[46] Vidal J, Muinelo L, Dalmases A, et al. Plasma ctDNA RAS mutation analysis for the diagnosis and treatment monitoring of metastatic colorectal cancer patients. Ann Oncol. 2017; 28: 13251332.

[47] Lin JK, Lin PC, Lin CH, et al. Clinical relevance of alterations in quantity and quality of plasma DNA in colorectal cancer patients: based on the mutation spectra detected in primary tumors. Ann Surg Oncol. 2014; 21(Suppl 4): 680-686.

[48] Szigeti KA, Galamb O, Kalmár A, et al. Role and alterations of DNA methylation during the aging and cancer. [A DNS-metiláció szerepe és megváltozása az öregedés és a daganatos betegségek kialakulása során.] Orv Hetil. 2018; 159: 3-15. [Hungarian]

[49] deVos T, Tetzner R, Model F, et al. Circulating methylated SEPT9 DNA in plasma is a biomarker for colorectal cancer. Clin Chem. 2009; 55: 1337-1346.

[50] Tänzer M, Balluff B, Distler J, et al. Performance of epigenetic markers SEPT9 and ALX4 in plasma for detection of colorectal precancerous lesions. PLOS ONE 2010; 5: e9061.

[51] Tóth K, Sipos F, Kalmár A, et al. Detection of methylated SEPT9 in plasma is a reliable screening method for both left- and rightsided colon cancers. PLOS ONE 2012; 7: e46000.

[52] Wasserkort R, Kalmar A, Valcz G, et al. Aberrant septin 9 DNA methylation in colorectal cancer is restricted to a single $\mathrm{CpG}$ island. BMC Cancer 2013; 13: 398.

[53] Tóth K, Wasserkort R, Sipos F, et al. Detection of methylated septin 9 in tissue and plasma of colorectal patients with neoplasia and the relationship to the amount of circulating cell-free DNA. PLOS ONE 2014; 9: el15415.

[54] Molnár B, Tóth K, Barták BK, et al. Plasma methylated septin 9: a colorectal cancer screening marker. Expert Rev Mol Diagn. 2015; 15: 171-184.

[55] Johnson DA, Barclay RL, Mergener K, et al. Plasma Septin9 versus fecal immunochemical testing for colorectal cancer screening: a prospective multicenter study. PLOS ONE 2014; 9: e98238.

[56] Ebert MP, Model F, Mooney S, et al. Aristaless-like homeobox-4 gene methylation is a potential marker for colorectal adenocarcinomas. Gastroenterology 2006; 131: 1418-1430.

[57] Henriksen SD, Madsen PH, Larsen AC, et al. Promoter hypermethylation in plasma-derived cell-free DNA as a prognostic marker for pancreatic adenocarcinoma staging. Int $\mathrm{J}$ Cancer 2017; 141: 2489-2497. 
[58] Pack SC, Kim HR, Lim SW, et al. Usefulness of plasma epigenetic changes of five major genes involved in the pathogenesis of colorectal cancer. Int J Colorectal Dis. 2013; 28: 139-147.

[59] Pedersen SK, Baker RT, McEvoy A, et al. A two-gene blood test for methylated DNA sensitive for colorectal cancer. PLoS ONE 2015; 10: e0125041.

[60] Symonds EL, Pedersen SK, Baker RT, et al. A blood test for methylated $B C A T I$ and $I K Z F I$ vs. a fecal immunochemical test for detection of colorectal neoplasia. Clin Transl Gastroenterol. 2016; 7: el37.
[61] Roperch JP, Incitti R, Forbin S, et al. Aberrant methylation of NPY, PENK, and WIFl as a promising marker for blood-based diagnosis of colorectal cancer. BMC Cancer 2013; 13: 566.

[62] Barták BK, Kalmár A, Péterfia B, et al. Colorectal adenoma and cancer detection based on altered methylation pattern of SFRPI, SFRP2, SDC2, and PRIMA1 in plasma samples. Epigenetics 2017; 12: 751-763.

(Barták Barbara Kinga dr., Budapest, Szentkirályi u 46., 1088 e-mail: bartak.barbara.kinga@gmail.com)

\section{Romhányi Orvostalálkozó - Lelkigyakorlat (manréza) orvosoknak Szár, 2019. augusztus 31. Moderátor: Prof. Dr. Szelényi Zoltán}

\section{Délelötti program}

goo Szentmise

$10^{00}$ Üdvözlések

Németh Norbert (polgármester)

Prof. Dr. Kellermayer Miklós: „Gyógyszer az örökhalál ellen”

$10^{30}$ Márfi Gyula (veszprémi érsek): A betegség hordozása és gyógyítása - mint szakrális cselekedet

$11^{00}$ Legeza József (teológus, görög katolikus parókus): A magyar görögkatolikus egyház története, helyzete

$11^{30}$ Rieger Tibor (szobrászművész): A művészet szellemi alapjai a Koronázó palásttól napjainkig

Romhányi-emléktábla megkoszorúzása

\section{Délutáni program}

$14^{00}$ Prof. Dr. Poór Gyula: A kórház legyen több, mint kórház

$14^{30}$ Prof. Dr. Losonczy Hajna: Az immunglobulin profilaxis jelentősége krónikus lymphoid leukémiában

$15^{00}$ Prof. Dr. Emődy Levente: Romhányi György klinikopatológiai szemléletének példája az utódgenerációk számára

$15^{30}$ Prof. Dr. Kondákor István: A hívő orvos

Genzwein Ferenc sírjának megkoszorúzása

A cikk a Creative Commons Attribution 4.0 International License (https://creativecommons.org/licenses/by/4.0/) feltételei szerint publikált Open Access közlemény, melynek szellemében a cikk bármilyen médiumban szabadon felhasználható, megosztható és újraközölhető, feltéve, hogy az eredeti szerző és a közlés helye, illetve a CC License linkje és az esetlegesen végrehajtott módosítások feltüntetésre kerülnek. (SID_1) 